\title{
"Before the Door that Opens on my Story": Samuel Beckett and Narrative as Detritus
}

\author{
Arka Chattopadhyay ${ }^{1}$ \\ IIT Gandhinagar
}

\begin{abstract}
The article weaves Lacanian psychoanalysis with narratology. It explores the Beckettian logic of narrative detritus in The Trilogy by examining stories, progressively "worsened" with every act of narration. Reading these obsessivecompulsive moments of narrative as failure, it sheds light on the various techniques and implications of this experiment that range from freezing a narrative into stasis to pushing it toward the limits of speculation and from forcing the narrative to revolve around its exterior to underlining its artifice through narratorial intrusions. The article focuses on the vestigial story-function to underscore the paradoxical status of Beckett's narrative impulse and demonstrates how the drift of these narrations relocates storytelling from the subjective pole of the "I" to the opacity of language as a field of the Other and finally into the originary and the terminal silence that conditions narrative. The article reads Beckett's assaults on the realistic narrative logic of the novel in tandem with an aporetic narrative logic that emerges from Lacanian psychoanalysis with its emphasis on the Real, as opposed to realism.
\end{abstract}

\section{Introduction}

This paper is an attempt to discuss the narrative act that connects psychoanalysis with literature. Both in the clinic and in the novel, we have someone telling the story of their life. The life-narrative we find on the couch as well as on the page is anything but linear and simple. The holes in clinical narratives often mark the traumatisme or the singular symptomatology of the particular analysand's subjective history. Thus an analyst has to pay attention to the failures in narration (slips, hesitations, digressions, stutters) on the couch that are an integral part of the emerging narrative. In Samuel Beckett's literary works, there is both a compulsion and a failure of telling stories. This double-bind becomes a fruitful place to think through narrative and narratology from a psychoanalytic vantage. As we shall see, the act of narrating one's life and associated lives of others, involves many enigmatic narrative gaps, dead-ends and a complex power dynamic. Situating the question in Beckett's mid- $20^{\text {th }}$ century trilogy of novels, Molloy, Malone Dies and The Unnamable, I will trace the ways in which Beckett enacts the multi-dimensional failure of simple storytelling. I will connect these problems with a Lacanian psychoanalytic understanding of how narrating a life encounters difficulties of subject-formation and stumbles into the unspeakable and the impossible-to-narrate. This is where we will come to locate narrative as detritus or waste in Beckett and in Lacan, thus in both literature and psychoanalysis.

${ }^{1}$ Correspondence concerning this article should be addressed to Prof. Arka Chattopadhyay, Assistant Professor, Humanities and Social Sciences, Office4/333a, IIT Gandhinagar, Gujarat, India. Email: arka.chattopadhyay@iitgn.ac.in

Language and Psychoanalysis, 2019, 8 (1), 69-82.

http://dx.doi.org/10.7565/landp.v8i1.1593 
In the past few years, we have noticed a newfound interest in Lacanian approaches to Beckett. Llewellyn Brown has written on voice and gaze in Beckett following Lacan's leads on the two topics. ${ }^{2}$ I have interpreted Beckett's use of mathematical formalization through later-Lacan's investment in mathematical discourse in relation to the unspeakable and impossible Real. ${ }^{3}$ Slavoj Žižek has drawn our attention to the importance of a writer like Beckett for Lacan's psychoanalytic project, in spite of Lacan's relative silence on Beckett, compared to his strong engagement with one of Beckett's mentors, the great Irish Modernist writer, James Joyce (see Žižek, 2009, n.p.). For example, Zizek has highlighted the importance of cut and rupture in Beckett and how this endears him to Lacan. He has also dealt at length with the drive and its compulsive aspect in Beckett—all relevant for our following discussion.

Beckett's Molloy articulates: "What I need now is stories, it took me a long time to know that, and I'm not sure of it" (p. 9). Moran responds to this when he says: "Stories, stories. I have not been able to tell them. I shall not be able to tell this one" (p. 132). In the space between these two statements or the cleft between the need for stories and the failure to tell them, Beckett preserves the minimal remains of a narrative. His work foregrounds a narrative arc which performs failure of representation and narration. Brian Richardson calls this "denarration" or narrative negation (168). Beckett negates the opening statements of Moran's narrative in Molloy with the novel's ending: "Then I went back into the house and wrote, It's midnight. The rain is beating on the windows. It was not midnight. It was not raining" (p. 170). As Debra Malina has shown in her study of narrative metalepsis in Beckett (see Malina, 2002, 25-62), it erases differences, not only between the intra-textual narrative layers but also between the textual and the extra-textual reality. Not to overemphasize narrative negation, let me say that it is only one of the two mechanisms in a narrative dialectic in which both construction and negation are significant. In Beckett's narrative dialectic, construction through negation and vice versa is not synthetic but prosthetic. An aporetic and unknowable impasse replaces narrative closure. I will return to this impasse through a Lacanian logic of the Real. In what Malina calls Beckett's "construction compulsion" (2002, p. 25), negation and construction are complementary and the narrative is precisely what remains at the terminus when the dialectical tension of negation and construction produces narrative detritus. Lacan's definition of language in Seminar $X X$ as "knowledge's hare-brained lucubration" (p. 139) on lalangue implies that lalangue is what remains of language when knowledge is separated from it: "the water of language happens to leave something behind as it passes, some detritus [...]" (Lacan, 1975, p. 16; emphasis added). I would argue that this minimal narrative remainder is marked by the Real antinomy of the letter (a tension or even a contradiction between the semantic level of the word, i.e., the signifier and the material and syntactic level of the word in the letter which marks the unspeakable Real), which installs an impasse to narrative signification.

\section{Narrative Closure and Signification}

Peter Brooks constructs an interface of narratology and Freudian psychoanalysis in terms of narrative as desire. In this spectrum, the end of a narrative finally produces

${ }^{2}$ See Brown's books, Beckett, Lacan and the Voice and Beckett, Lacan and the Gaze.

${ }^{3}$ See my book, Beckett, Lacan and the Mathematical Writing of the Real.

Language and Psychoanalysis, 2019, 8 (1), 69-82.

http://dx.doi.org/10.7565/landp.v8i1.1593 
readerly gratification by offering an object which either fulfils or betrays narrative expectations. For Brooks, the end of a narrative retroactively gives it full significance, like the period that completes the sense of a sentence: "If the motor of narrative is desire, totalizing, building ever-larger units of meaning, the ultimate determinants of meaning lie at the end, and narrative desire is ultimately, inexplicably, desire for the end" (p. 52; emphases in the original).

As opposed to Brooks's thesis that narrative end is signifying, I would argue that narrative end in Beckett hardly offers a closure. Narrative jettisons itself into a terminality that does not signify the narrative but installs itself as a non-signifying Real. The end of a narrative activates Beckettian "metalepsis" (a narratological technique to mark the breakdown of difference between multiple layers of a narrative wherein material from one discrete layer intrudes the other) and produces a jettisoning effect, turning the end into an impasse and not a retrospective generator of signification. Highlighting this substitution of a signifying narrative closure with a non-signifying narrative impasse and the implications it could have for a psychoanalytic narrative logic, I will turn, not to the Beckettian narrative as a (w)hole but to the tiny "ill-said" stories within The Trilogy that persist as bristling remainders in Beckett's narrative dialectic. These meta-diegetic stories are told in increasingly worsening ways: "I tell this story worse and worse" (Beckett, 2003, p. 102).

Self-reflexively tedious repetitions, ludicrous compressions and tangential narrative doors characterize these vestigial stories. In this narrative experiment, techniques range from freezing narrative motion into ambivalent stasis to pushing it towards the furthest limits of speculation, from forcing the narrative to revolve around its exterior to disclosing its constructedness through narratorial intrusions. I would argue that these stories sabotage assumptions of narrative reality ' replace it with a logic of the Real, defined as the impossible by Lacan: "this impossibility by which a real is defined" (Lacan, 1998b, p. 144). They enact the paradoxical status of Beckett's narrative impulse where the nothingness of stories meets the necessity of storytelling. They shift the emphasis of narration from the subjective locus of the "I" to the enigma of language as the order of the Other and finally into the originary as well as the terminal silence that monitors narrative. In a psychoanalytic understanding, narrative becomes a linguistic and discursive site in which the subject's desire is alienated in the desires of significant Others. The narrative act exposes this dialectical oscillation of power between the subject and the linguistic field of the Other.

\section{Narrative Detritus in 'The Trilogy' Storytelling, Non-Relation and Death}

The first failed narrative in The Trilogy concerns Molloy's early effort to envisage an encounter between $\mathrm{A}$ and $\mathrm{C}$, the two wayfarers from vast distance in a gradually forming valley as they fleetingly meet one another, soon to go their separate ways. The fragmented narrative act indicates a writer's first attempt to enform a stillborn story. The alphabetical names and the anonymous setting slowly start acquiring local colors and yet the generic narrative never flourishes. The metonymic accumulation of realistic details and the possibilities of narrative expansion remain futile as $\mathrm{A}$ and $\mathrm{C}$, instead of initiating a conversation as a form of relationality that could extend into a story, halt "face to face" and "breast to breast" (p. 5). From the narrator's distant presence, it is impossible to understand whether they know each other and stop to

Language and Psychoanalysis, 2019, 8 (1), 69-82.

http://dx.doi.org/10.7565/landp.v8i1.1593 
share mutual greetings or simply pause at the sight of a fellow human being. As this false start dissipates, the narrator becomes increasingly unsure about who $\mathrm{A}$ and $\mathrm{C}$ are and the last we hear of them is the announcement of greater uncertainty as the narrator expresses his doubts about recognizing them in the future. This narrative remains inanimate and fleeting, but what fails it is the narrator's ignorance and his absolute inability to reach and read his characters. This aspect of not knowing which leads to narrative failure is important.

Malone's sickbed narratives to pass time as his time passes into death, dramatize another storytelling act in The Trilogy. At the outset, Malone promises to tell himself four discrete stories: "one about a man, another about a woman, a third about a thing and finally one about an animal, a bird probably" (p. 175). When he starts telling them, the stories inter-contaminate one another. The story of the first boy-man, Saposcat merges with the story of the "bird". The bird is not only a literal presence with horses and hens in his friend's family but a symbolic presence as well. At a certain point, his story suddenly mutates into the story of Macmann and his experience in the mental asylum where he has a bizarre affair with his attendant Moll. It is in this story that we have the most important function of "a thing", i.e., the Christ-shaped solitary tooth that sparkles inside Moll's bare mouth. This is how the four different stories overlap one another. This metaleptic collapse of meta-diegetic levels (discrete layers framed by the narrative, each of which nestles a story in itself), reaches a climax when the novel ends inside Macmann's asylum story. Malone dies inside his story. We never return to the frame-narrative, i.e., his sickbed act of telling stories about human beings, animals and inanimate objects to himself. The last sentence of the novel, devoid of punctuation mark, hovers on the tipping point with the repeated alternations of "or". The sentence corporeally sinks into the narrative silence of death as Beckett flips the horizontal arrangement into the vertical:

or with it or with his hammer or with his stick or with his fist or in thought in dream I mean never he will never

or with his pencil or with his stick or

or light light I mean

never there he will never

never anything

there

any more (p. 281)

As Malone's death is conflated with the death of his stories, the narrative end, instead of embodying a closure, creates a collapse where the storytelling subject is internalized in his own narrative and his death is also encapsulated by it. This end does not give meaning to Malone's narrative life but, like death, it becomes a figure of the unknowable, slotted in the undecidable breach between the frame-narrative and the meta-diegetic narratives. The reference to Malone's pencil and stick in the quote 
above signals narrative metalepsis by bridging the gap between Malone's frame narrative and the meta-narrative about Macmann.

Let us look at the Saposcat story to trace its narrative impasse. The Sapo story is consistently interrupted by comic narratorial intrusions that expose its fictional status: "What tedium" (p. 181), "Sapo had no friends-no, that won't do" (p. 183) and "This is awful" (p. 185). Apart from these self-disparaging remarks about the narrative, Malone expresses his anxieties about losing his epistemic grasp over the story: "Already I forget what I have said. [...] Soon I shall not know where Sapo comes from, nor what he hopes" (p. 183). The storyteller's ignorance about the shape of his stories and the life of the others within them is fundamental to this narrative impasse. Malone is aware that leaving a little door for darkness to seep into his story can ring its death-knell:

For I want as little as possible of darkness in his story. A little darkness, in itself, at the time, is nothing. You think no more about it and you go on. But I know what darkness is, it accumulates, thickens, then suddenly bursts and drowns everything.

Just as Sapo's teachers cannot get anything into his head, the storyteller cannot read his protagonist. For Malone, Sapo remains opaque. This opacity of the material is a room for narrative failure. The analogy between the teacher and the storyteller is important because as we shall see, Beckett keeps returning to this pedagogic regime of storytelling. Martha Nussbaum has foregrounded this aspect in her reading of The Trilogy. Both teaching and storytelling are in shambles in Beckett. The more Sapo reads, the worse his results get and he becomes increasingly unreadable for the narrator. Sapo's strange walk with halts and sudden starts, resembles the movement of the narrative as it oscillates between motion and stasis.

Sapo's stay at the neighborhood of the Lamberts - fellow farmers with horses, mules and hens around their house, introduces another failure of the story to take off. He goes and sits in the kitchen of the Lamberts. When they busy themselves in the day's labours, Sapo is alone in the kitchen as light fades in and out of the room. In the darkening room, rays of light keep entering through the narrow slits, only to die their little deaths there. This darkening room in which silent Sapo sits alone, encapsulates a narrative darkness where the story, bereft of all possible dialogues and encounters, fails to launch itself. Non-relation is heightened as a grey hen habitually comes into Sapo's kitchen penumbra. It is sensitive to Sapo's presence and remains suspended between movement and stillness in a blinking state of anxiety. Yet both Sapo and the hen-and sometimes more than one hen-exchange gazes that meet but do not usher into any symbolic exchange. The failed communication between the boy and the animal marks another narrative impasse here. The narrator restores the question of ignorance with a speculation: if it is "a" grey hen or "the" grey hen and the ways of determining the precise number of grey hen or hens in the Lamberts' possession. As the kitchen abruptly sinks into a glistening dark, Sapo gets up and leaves the Lamberts' house without a word and disappears. When the narrator follows this up

Language and Psychoanalysis, 2019, 8 (1), 69-82.

http://dx.doi.org/10.7565/landp.v8i1.1593 
with the episode of Mr. Saposcat, Sapo's father bringing him a new fountain pen with a bird designed on its lid, it extends Malone's promised theme of a bird by substituting the flesh-and-blood hen with the inanimate fakery of a bird. The animal mutates into a thing here as Malone's narrative themes weave into one another. This metamorphosis of the animal into an object marks a symbolic or narrative death. The bird-pen cannot improve Sapo's performance in school-exams. It ends up being the cause of a fight between his parents. This narrative thing kills the bird by transfixing it into an inanimate object that fails to improve Sapo's academic performance.

This symbolic death of the bird is immediately followed, in the Lamberts' narrative, by the actual death of Old Lambert's mule. Sapo watches its burial. This animal death could be seen as homology for a dying narrative. The mule's corpse is as contorted and immovable as the story itself: "The forelegs were stretched out straight and rigid, the hind drawn up under the belly. The yawning jaws, the wreathed lips, the enormous teeth, the bulging eyes, composed a striking death's head (p. 205)".

This "death's head" will soon be followed up by its Latin "caput mortuum" in Texts for Nothing. Alchemically speaking, "caput mortuum" is the leftover of a chemical operation and the expression is not without its Lacanian echoes. For Lacan, it relates to the constitution of dead letters in the Real (Lacan, 2006, p. 38) and in these instances, we are looking at a range of narrative deaths that metaphorise "the essentially localized structure of the signifier" (Lacan, 2006, p. 418) as a Lacanian letter. In Beckett, the caput mortuum of the narrative is that which remains after the dialectic yields its residue in the form of a detritus. Animal deaths proliferate as Old Lambert becomes resigned about his old mules in the slaughter-house and Mrs. Lambert returns in the evening to Sapo's darkening kitchen with a white rabbit to follow up on the black mule. When the Lamberts get ready for their rabbit dinner, Sapo is on his way back home. As Mrs. Lambert returns with the dead rabbit and Old Lambert decides to kill Whitey, the partner of the dead mule, the day after, Sapo tells Mrs. Lambert that he would never return to the farm. The Lamberts-episode and Sapo's story end with a portrait of Mrs. Lambert, feeling through the inert objects in the enigmatically darkening kitchen with her fretful family thoughts. Her daughter tells her that Sapo has quit them. This irreversibility of Sapo's departure is articulated through another figure of death:

Then as people do, when someone insignificant dies, they summoned up such memories, as he had left them, helping one another trying to agree. But we all know that little flame and its flickerings in the wild shadows. And agreement only comes a little later, with the forgetting. (p. 211)

This final trope of Sapo's metaphorical death for the Lamberts acts like a signature for the death of Sapo's story. After an extended digression and interruption due to loss of consciousness and the pencil slipping from Malone's hand, when he returns to his story, he cannot call his character Sapo anymore and decides to name him Macmann. This is a transformative point. The narrative trope of death finishes off young Sapo and substitutes him with the old Macmann. Sapo's decision not to return to the Language and Psychoanalysis, 2019, 8 (1), 69-82. 
Lamberts could be seen as his reaction against their violence to animals. This is implied by the narrator's reflective detour on the varying tenacity of hens, rabbits and, pigeons facing a deadly blow. If it is Sapo's story and not the Lamberts', why does Sapo's permanent exit from the Lamberts' farm become the death-knell for Sapo's story? Given that Sapo is the protagonist, his decision not to return to the Lamberts could have marked the end of the Lamberts episode. But it becomes a collapsing point for the whole story, which shows how Sapo's story had already become the Lamberts' story. This narrative fluctuation is symptomatic of decentering and alienation. This is how narrative act itself becomes a tool of alienation for the subject. When we tell our stories in which Others creep in, on occasions, these stories pull the rug under our own feet as they become stories of Others. We become alienated in our own stories. It is in this way that Sapo's story turns Lamberts'. Narrative impasse is caused by the inversion of protagonicity as a narrative principle, the trope of death and its literalization. It is also prompted by the subjective solitude of figures in the narrative who cannot establish any relationality. This is a world of non-communication and inertia that does not allow a story to expand. It contracts the story into a minimal remainder like the fleeting memory of the dead, as in the aforementioned passage.

\section{Other's Narration, Power, and Pedagogy}

In The Unnamable, story-function shifts toward alterity. The stories told by the unnamable are filtered and circulated through Basil and Mahood-figures of nonself - in relation to whom, he struggles to define his selfhood. The unnamable narrator admits that he is framed by these words of the Other. This signals that he is alienated from himself in and through these stories: "Having nothing to say, no words but the words of others, I have to speak" (p. 308), or "[...] I'm in words, made of words, other's words [...]" (p. 379). These are not his stories but Basil's or Mahood's. When they are his, insofar as they delineate him, they are mediated by the Other's words that make him an Other in these narratives. The self is alienated into the Other through the storytelling function in The Unnamable. In the acute linguistic consciousness of the Beckettian subject, speech in a Lacanian way, registers the locus of the Other. For the unnamable, the regime of words introduces a tormenting teaching where speech is imposed on the subject: "It's a poor trick that consists in ramming a set of words down your gullet on the principle that you can't bring them up without being branded as belonging to their breed" (p. 318). Story function is subsumed in this disciplining regime of speech which not only works as an Other but dominates the subject when the unnamable tries to put an end to speech and fall headlong into a silence that would not pause speech but get rid of it altogether.

This desired silence is not interruptive to speech but external to the Symbolic. The unnamable's search for this narrative end is the novel's compulsive drive. Though this seems to echo Peter Brooks's narrative desire, the silence that envelopes this narrative end never arrives. The end of the novel gestures toward this silence axiomatically but it remains a tangent to the narrative. The terminal antinomy of The Unnamable is "you must go on, I can't go on, I'll go on" (p. 407). It points to an impossibility of closure as the narrative infinitely involutes between the negation of "no" and the continuity of "on". The elusive silence at the end is still a matter of future. This future is ambiguously divided by the present: "[...] it will be the silence, where I am, I don't know, I'll never know, [...]" (p. 407; emphases added). Let us note the use of two tenses in the same sentence. Because this silence lies outside knowledge, there is no knowing if one is or isn't in the silence. It frames the narrative as a liminal point. This Language and Psychoanalysis, 2019, 8 (1), 69-82.

http://dx.doi.org/10.7565/landp.v8i1.1593 
strictly unreachable silence that all speech and stories come from and vanish into, is impossible to incorporate in a narrative; and yet the Beckettian narrative is obsessed with circulating this silence like a potter constitutes the void at the centre of his pot, to use Lacan's example from Seminar VII. The potter constitutes the rim around the void, giving shape to the void that remains both inside and outside, i.e., within the pot as well as outside it (Lacan, 1992, p. 121).

This silence is Real inasmuch as it resists Symbolization in language and yet it is that which propels the Symbolic act. Lacan uses the neologism "extimate" to mark the internally excluded nature of this Real (Lacan, 1992, p. 139). It is inside as well as outside. The inside-outside distinction collapses in the face of this unsymbolizable Real. Instead of attaining it, the narrative revolves around the Real, like psychoanalytic drives that go round and round their object. When the subject finally thinks he is in this silence but cannot know, the Real becomes extimate in relation to the narrative. The Real Silence is both reached and not reached and the Real is antinomically inscribed in this present, invading the future where the future wrenches itself away from the present. This is the impossible logic of the Real that frames the Beckettian narrative. When Lacan, in his supplementary modal logic, adds the fourth figure of the "impossible" to the Aristotelian triad of the "necessary", the "contingent" and the "possible", it takes contradiction out by incorporating it within the logical square. This is how, for Lacan, logic passes into what he calls the "science of the Real". In the eighth session of Seminar XXI, following Freud that the logic of the unconscious does not know the principle of contradiction, Lacan reflects that the unconscious prefers a "both and" over an "either or" logic in the formation of the impossible as the Real:

And this indeed is why what I marked about the impossible, namely, what separates, but otherwise than is done by the possible, it is not an either-or, it is a both-and. In other words, that it should be at the same time $p$ and non- $p$ is impossible, it is precisely what you reject in the principle of contradiction.

(Seminar XXI, session of 19.2.1974, emphasis added)

With this installation of the impossible, narrative stops and continues. The Real makes narrative closure impossible. In Lacan's orthographic schema, it is a writing that "doesn't stop not being written" (Lacan, 1998b, p. 94). For Lacan, the Real is a narrative in which the negation of narrative never stops being written; this negation is written again and again ad infinitum and, hence, Beckett would say, "you must go on, I can't go on, I'll go on".

Let me explore some vestigial narratives in The Unnamable to illustrate this logic of the Real that insists on narrative limit and the impossibility of knowing the narrative from the storyteller's perspective. This Real non-knowledge collapses narrative closure. The first sustained narrative act in The Unnamable concerns the story of his "world tour" spanning multiple centuries at the end of which, he returns to the remains of his devastated family, perished from sausage-poisoning. The unnamable 
tells this story only because it is a task imposed on him. He hopes to walk out of stories and speaking by finishing this telling. This is a story in which he mistakes himself for Mahood, thus, characterizing the narrative as a performance in selfalienation (Beckett, 2006, p. 311). When the unnamable, lacking a leg and an arm and having just enough armpits to carry a crutch, wheels around his family, the members anxiously see him from a distance. By the time he reaches home, they are all dead and the place is full of stench and rotten body parts. The story ensures that there is no room for narrative relationality and no communication between the unnamable and his family members. While this story is obsessed with death and biological detritus, the story itself gestures toward a narrative detritus when the unnamable narrator crosses out the entire story:

But enough of this nonsense. I was never anywhere but here, no one ever got me

out of here. Enough of acting the infant who has been told so often how he was

found under a cabbage that in the end he remembers the exact spot in the garden

and the kind of life he led there before joining the family circle. (pp. 317-318)

The story is easy to falsify because it comes from the Other as a narrative imposition. It subjects the subject to the Other's conception of his subjectivity. The narrative negation here is imbued with an element of dissidence as the subject denies fictional demand for identification through narrative pedagogy. In this narrative dialectic of construction through negation, the prosthesis is not only the unnamable's crutch but also the narrative detritus, produced by the subject's non-coincidence with the Other's fiction. The subject does not know and cannot verify the story. The narrative act is halted by this ignorance. It tips the story onto the side of the unspeakable Real but there is no proof to demonstrate the falsity of the narrative. The fact that the unnamable does not remember cannot be an evidence, owing to the inevitability of human forgetting. It is an impossible and unknowable juncture in the narrative where it can neither go on nor stop for good and therefore it must mutate into another story. By virtue of the Real, these stories do not stop not being written, as narrative negation never produces a void. Something remains, be it Lacan's double-negation ("doesn't stop not being written") that cannot be neutralized into an affirmation or Beckett's ambivalence where the subject denies the Other's fable of himself but can neither prove nor disprove it. In this impasse lies the impossibility of a logic that passes into the Real by evoking antinomies.

The next story of Mahood, thrust upon the unnamable, produces a narrative mutation. It is about the unnamable's stay in a glass jar at the meatshop. The shop is owned by a woman who not only uses his skull as an object of display and advertisement for the chop-house but also cares for it with an occasional "maternal instinct" (p. 323). Though this is a story about the unnamable, it mediates through Mahood as the Other and alienates his subjectivity by itemizing his skull as an object for the Other's gaze. In this story, the unnamable experiences, though does not fully understand "the boon of tears" (p. 322) as they flow from his eyes unceasingly when the proprietress covers his jar with a tarpaulin on winter evenings. He speculates if tears signify his gratitude towards the lady. But he cannot be sure because he acknowledges this care to be cover Language and Psychoanalysis, 2019, 8 (1), 69-82. 
for a simple logic of "capital". After all, the unnamable serves the best and the most memorable "landmark" and "advertisement" for her shop (pp. 322-23). Noncommunication rules when the unnamable, bereft of speech, props his head out of the jar and tries to communicate to his proprietress that he feels cold and wants to be shrouded. She fails to read his signs and things do not change: "[...] we made balls of it between us, I with my signs and she with her reading of them" (p. 323). The unnamable almost identifies with this story but he also remarks how the Others often stop stories at one point, just when he is beginning to invest in them subjectively and resume them at a different point. This confuses him and gives him an illusion of intermittent relief and freedom. Narrative resumptions are therefore part of the Other's strategies. These are mutations and not resumptions. The mutation from one story to another is not consistent because they resume the fiction of the subject at a radically different and unrecognizable juncture: "[...] I mean instead of resuming me at the point where I was left off, they pick me up at a much later stage [...]" (p. 324).

In what remains of this story, the unnamable starts to shrink inside the jar, as if to protest his objectification. This irritates the woman. She raises him by filling the bottom of the jar with sawdust. But with every passing day, he becomes so miniscule that she can hardly see or use him. This is where the story disintegrates with the subject on the brink of complete disappearance, contracted into an immovable detritus: eyes, ears, and a head - a minimal narrative remainder. Almost immediately after the story's dissipation, the narrator marks the logic of the Real: "[...] being admitted to that peace where he neither is, nor is not, and where the language dies that permits of such expressions" (p. 328). This indeed is Beckett's own articulation of a Lacanian Real logic where the axiom of the inexpressible constitutes the expressive act. In the impossible antinomy of the "is and the is not" lies the Real. As the unnamable reflects, "it's a lot to expect of one creature" (Beckett, 2006, p. 328) to reach that Real. As Lacan in Seminar XI formulates, it can be axiomatically touched by an encounter. This is what The Unnamable sets out to inscribe. In the fifth session of Seminar XI, Lacan discusses the difference between Aristotle's terms, tuché and automaton to observe that the Real is not a matter of deterministic fortune but a question of chance. The Real for Lacan is an impossible encounter (1998a, p. 53-64). It is an inscribed encounter and, in Beckett's work, this Godot-like "missed encounter" becomes an irreducible signature of the Real.

The final narrative remnant in The Unnamable is evoked in a pedagogic context, with an instrumental lesson in emotions, especially that of love. The unnamable repeats this story from the Other with ironic compression:

They love each other, marry, in order to love each other better, more conveniently,

he goes to the wars, he dies at the wars, she weeps, with emotion, at having loved him, at having lost him, yep, marries again, in order to love again, more conveniently again, they love each other, you love as many times as necessary, as necessary in order to be happy, he comes back, the other comes back, from the wars, he didn't die at the wars after all, she goes to the station, to meet him, he dies Language and Psychoanalysis, 2019, 8 (1), 69-82. 
in the train, of emotion, at the thought of seeing her again, having her again, she weeps again, with emotion again, at having lost again, yep, goes back to the house, he's dead, the other is dead, the mother-in-law takes him down, he hanged himself, with emotion, at the thought of losing her, she weeps, weeps louder, at having lost him, at having lost him, there's a story for you, that was to teach me the nature of emotion, $[\ldots]$ (p. 399)

In this parody of conventional novelistic narrative, Beckett compresses a realistic sentimental novel in less than two hundred words. This story leads to a question or a hypothesis. It jettisons closure and asks an unanswerable question in the spirit of the Real. Lacan defines the Real not only as impossibility and unknowability but also as "an impasse of formalization" (Lacan, 1998b, p. 93). The narrative form here stumbles against a Real impasse. Following the story, the unnamable interrogates its narrative logic by asking a question that emerges from the demand of the realism, that shapes its conventional and contrived plot:

[...] that must be the mother-in-law, I don't know, it must be her son, since she cries, and the door, the house-door is bolted, when she got back from the station she found the house-door bolted, who bolted it, he the better to hang himself, or the mother-in-law the better to take him down, or to prevent her daughter-in-law from re-entering the premises, there's a story for you, it must be the daughter-in-law, it isn't the son-in-law and the daughter, it's the daughter-in-law and the son, how I reason this evening, it was to teach me how to reason $[\ldots]$ (p. 400)

The unnamable exercises the reasoning, taught through this narrative but it produces an aporia. It is not known who bolted the door. In this typical melodramatic situation, one would hardly care to answer a question about such an insignificant detail. The question falls within realism because it concerns the metonymic accumulation of details in a realistic text, keen on maintaining its logical consistency. This realistic question exposes the realistic narrative to a point of ignorance where the narrative mutates into hypothetical speculation, marking its tangential exterior: "[...] who bolted the door, and for what purpose, I'll never know, there's a story for you [...]" (p. 400). This question about the door activates the Real and bores a hole into the epistemic narrative foundation. The story does not have the question in it. The question, like the Real letter, is subjective. The unnamable sabotages the story with this question. This is a singular act of subjective subversion. The question is a Real detritus that mutates the "door" from a signifier to a letter.

Language and Psychoanalysis, 2019, 8 (1), 69-82.

http://dx.doi.org/10.7565/landp.v8i1.1593 
After this story, the unnamable returns to the "door" in an abstract context. The wooden door is abstracted into a narrative door on the brink of the Real silence. This transformation resembles the mutation of the real bird into the bird-pen in Malone Dies. As the door becomes a word from a wooden thing, it is rendered into the Real letter of the subject's final question. This question does not come from the Other but constitutes his singularity in lalangue. This door is located at the terminal cusp of narrative and silence: "[...] perhaps it's the door, perhaps I'm at the door [...] it's I now at the door, what door, what's a door doing here, it's the last words, the true last [...]" (p. 407). Here the narrator brings back the important distinction between a lasting silence which he calls an unreachable "dream of a silence" (p. 407) and another silence which does not last. I would characterize the first as a Real silence, outside of the Symbolic, while the latter is a Symbolic silence that pauses speech-acts and itself speaks. The silence, which does not symbolize anything, is the unbreakable silence of the Real. The door is the margin of this Real silence. It can open out into the Real or open inward into the story. But, like the wooden door, this Real "door" punches a hole in knowledge by not opening at all: "[...] perhaps they have said me already, perhaps they have carried me to the threshold of my story, before the door that opens on my story, that would surprise me, if it opens [...] (p. 407)".

The "they" here refers both to the words as well as the Others who have introduced the story-function into the subject. These words and Others or these words as Others have "said" the unnamable throughout. Though this would give an impression of complete capitulation, I have marked how the said subject has also subverted the regime of the Other's narrative by asking questions and failing their narrative lessons. The narrative act may constitute its own hegemony of power by alienating the narrative subject in the story of Other(s). But neither Beckett's nor Lacan's work upholds this politics of mastery. If at all, they both resist the narrative politics of masterfulness by underlining narrative failure. The only category of master Lacan identifies himself with, is the Zen Buddhist master. As he clarifies in the overture to his first seminar:

That is how a buddhist master conducts his search for meaning, according to the technique of zen. It behoves the students to find out for themselves the answer to their own questions. The master does not teach ex cathedra a ready made science; he supplies an answer when the students are on the verge of finding it. This kind of teaching is a refusal of any system. It uncovers a thought in motionnonetheless vulnerable to systematisation, since it necessarily possesses a dogmatic aspect. (Lacan, 1991, p. 1)

In the above passage, Lacan connects Buddhist pedagogy with Freud's teachings and underscores how both are anti-dogmatic and resist any authoritarian or dictatorial mastery. The master in the Lacanian tradition allows the analysand to find their answers, rather than dictating their own to those on the couch. In the pedagogic 
moments, studied in Beckett, we have seen an intense problematization of this trope of masterful omnipotence vis-à-vis narrative.

To return to The Unnamable, the hypothetical opening of the door would open the ambivalent future of entering the Real silence where the subject would finally be at one with his self-articulation in the "I". But this future, driven by the present, as we have seen above, is only an undecidable Real tangent. In the tripartite Lacanian subject, this "signifying cut" of the Symbolic order where the subject speaks and is spoken by language, points to the Real of the subject. This Real can only be registered as an impasse, a rift or a discontinuity: "The cut made by the signifying chain is the only cut that verifies the structure of the subject as a discontinuity in the real" (Lacan, 2006, p. 678). The Real subject, like the Real silence outside language, remains a hole which the narrative constitutes as a detritus after the exhaustive dialectic of construction through negation and vice versa finishes its work. This remainder is a Real crack that punches a gaping hole in the signifying apparatus of language and its narrative constructions.

Fundamentally speaking, psychoanalysis can never entirely do without narrative because the analysands always constitute their clinical history through freeassociation. In spite of assaults, there is still narrative in Beckett, reduced to the mathematical and corporeal dimension of the letter. The analysand's speech similarly signs narrative in the letter of a detritus. This cannot be a linear and expansive realistic narrative. In Beckettian terms, if the unnamable is in the analysand's position, Lacan does not want to become his master like Basil or Mahood by imposing a narrative on him. This is precisely the tradition of ego-psychology that Lacan resisted. For him, psychoanalysis is about the analysand. The analyst's mastery is supposed be trashed by the end of analysis. The Lacanian analyst is not a master. They have no messianic secret to cure the analysand with. On the contrary, the Lacanian trajectory of analysis lies in trashing the transferential mastery of the analyst as a "subject supposed to know"-Lacan's formula for transference. This jettisoning of the analyst as a locus of supposed epistemic mastery exposes the fact the analyst does not know anything other than what the analysand speaks on the couch. Lacan does not want to use narrative as a form of power and domination. It is at this point that his work resonates with Beckett who not only exposes narrative linearity of realism as a form of epistemic power but also punches a hole in that epistemic narrative power with the logic of the Real by insisting on ignorance and impasse. In Beckett, what remains after the exhaustive narrative dialectic of constructive negation and negative construction is a narrative detritus in which realism is subverted by the Real.

\section{References}

Beckett, S. (1995). The complete shorter prose: 1929-1989. New York, NY: Grove.

Beckett, S. (2003). The complete dramatic works. London, UK: Faber.

Beckett, S. (2006). The grove centenary edition volume II: Novels. New York, NY: Grove.

Beckett, S. (2009). Company, ill seen ill said, Worstward Ho, stirrings still. London, UK: Faber.

Brooks, R. (1992). Reading for the plot: Design and intention in narrative. Cambridge, UK: Harvard University Press.

Language and Psychoanalysis, 2019, 8 (1), 69-82.

http://dx.doi.org/10.7565/landp.v8i1.1593 
Brown, L. (2016). Beckett, Lacan and the voice. Stuttgart, Germany: Ibidem-Verlag. Brown, L. (2019). Beckett, Lacan and the gaze. Stuttgart, Germany: Ibidem-Verlag. Chattopadhyay, A. (2019). Beckett, Lacan and the mathematical writing of the real. London, UK: Bloomsbury.

Lacan, J. (2006). Écrits. (B. Fink, H. Fink, \& R. Grigg, Trans.). London, UK: Norton.

Lacan, J. (1991). The seminar Of Jacques Lacan: Book I: Freud's papers on technique 1953-1954. (J. Forrester, Trans.). New York, NY: Norton.

Lacan, J. (1992). Book VII: The ethics of psychoanalysis 1959-1960. (Dennis Porter, Trans.). New York, NY: Norton.

Lacan, J. (1998a). The four fundamental concepts of psychoanalysis. (A. Sheridan, Trans.). New York, NY: Norton.

Lacan, J. (1998b). The seminar Of Jacques Lacan: Book XX: On feminine sexuality: The limits of love and knowledge, 1972-73. (B. Fink, Trans.). New York, NY: Norton.

Lacan, J. (1974). The seminar of Jacques Lacan: Book XXI; The names of the father. (C. Gallagher, Trans.). Retrieved from http://www.lacaninireland.com/web/translations/seminars/

Lacan, J. (1989). Geneva lecture on the symptom: 1975. (R. Grigg, Trans). Analysis 1. Melbourne, Australia: Centre for Psychoanalytic Research, 7-26.

Malina, D. (2002). Breaking the frame: Metalepsis and construction of the subject. Columbus, OH: The Ohio State University Press.

Nussbaum, M. C. (1990). Narrative emotions: Beckett's genealogy of love. In Love's knowledge: Essays on philosophy and literature (pp. 286-313). Oxford, UK: Oxford University Press.

Richardson, B. (2001). Denarration in fiction: Erasing the story in Beckett and others. Narrative: Contemporary Narratology, 9, 168-175.

Žižek, S. (2009). Beckett with Lacan. Lacanian Ink. Retrieved from http://www.lacan.com/article/?page_id=78 